\title{
Chemical and isotopic switching within the subglacial environment of a high Arctic glacier
}

\author{
General Research paper \\ Peter Wynn $^{\mathrm{a}, *}$, Andrew Hodson ${ }^{\mathrm{a}}$, Tim H.E. Heaton ${ }^{\mathrm{b}}$ \\ ${ }^{a}$ Department of Geography, University of Sheffield, Winter St., Sheffield S10 2TN, UK \\ ${ }^{b}$ NERC Isotope Geosciences Laboratory, British Geological Survey, Keyworth, Nottingham \\ $N G 125 G G, U K$ \\ * Corresponding author. Tel. +44(0)114 222 7900. E-mail address: p.wynn@sheffield.ac.uk
}

Keywords: Isotopes; Microbial; Redox status; Subglacial 


\begin{abstract}
Natural environmental isotopes of nitrate, sulphate and inorganic carbon are discussed in conjunction with major ion chemistry of subglacial runoff from a High Arctic glacier, Midre Lovénbreen, Svalbard. The chemical composition of meltwaters is observed to switch in accordance with subglacial hydrological evolution and redox status. Changing rapidly from reducing to oxidizing conditions, subglacial waters also depict that ${ }^{15} \mathrm{~N} /{ }^{14} \mathrm{~N}$ values show microbial denitrification is an active component of nutrient cycling beneath the glacier. ${ }^{18} \mathrm{O} /{ }^{16} \mathrm{O}$ ratios of sulphate are used to elucidate mechanisms of biological and abiological sulphide oxidation. Concentrations of bicarbonate appear to be governed largely by the degree of rock:water contact encountered in the subglacial system, rather than the switch in redox status, although the potential for microbiological activity to influence ambient bicarbonate concentrations is recognised. Glaciers are therefore highlighted as cryospheric ecosystems supporting microbial life which directly impacts upon the release of solute through biogeochemically mediated processes.
\end{abstract}




\section{Introduction}

Traditional models of meltwater solute acquisition within subglacial environments assume a two component mixing model wherein solute is acquired through purely inorganic chemical reactions prior to meltwater evacuation from the glacier bed (Collins 1978; Collins 1979; Tranter and Raiswell, 1991; Tranter et al., 1993). The two components of subglacial bulk meltwater are termed quick flow and delayed flow, identifying the residence times distinctive to each water type (Tranter et al., 1993). Whilst each component is ultimately derived from summer precipitation, supraglacial snow and ice melt, quick flow represents meltwater in rapid transit through the glacial system, most likely through well defined conduits (Rothlisberger, 1972; Nye 1973; Hooke et al., 1990), and delayed flow pertains to the slow passage of water at the ice-bedrock interface near the sole of the glacier. Depending upon the state of the glacier bed (hard rock or soft sediment), this latter component is thought to be subject to either attenuated flow through tortuous linked cavity networks (Lliboutry, 1968), films of basal melt (Weertman, 1972), or water saturated till (Boulton and Hindmarsh, 1987). The relative importance of each system has been found to vary on a spatial and temporal basis, such that quick flow drainage typically develops at the expense of the delayed flow component as the snow line retreats upglacier during the ablation season (Nienow et al., 1998). Acquisition of solute by each water type was thought to be determined solely through the degree of rock-water contact encountered in each environment and by the presence of atmospheric oxygen and carbon dioxide gases in solution (Tranter et al., 1993). Thus, quick flow waters are often assumed to have low solute loads. In contrast, delayed flow waters have relatively concentrated solute loads, limited according to the availability of dissolved gases. However, there is now a growing body of evidence to suggest the acquisition of 
solutes within the subglacial environment is not governed solely by inorganic processes, but rather through the microbial mediation of weathering reactions (Sharp et al., 1999; Skidmore et al., 2000; Parkes, 2001). This has produced something of a paradigm shift in the understanding of glacial hydrochemistry, decoupling the acquisition of solute from the necessity of having dissolved atmospheric oxygen and carbon dioxide in solution. Alternative oxidising agents are utilised through microbial catalysis, enabling the continued acquisition of solute even after dissolved atmospheric gases have been depleted. This has been employed to explain anonymously high concentrations of sulphate and bicarbonate present in the subglacial environment of some glaciers when assuming dissolved atmospheric oxygen and carbon dioxide were the sole agents of oxidation and carbonation reactions respectively (Bottrell and Tranter, 2002; Tranter et al., 2002, Wadham et al., 2004). Whilst quick flow meltwaters are likely to pass through the glacial system with such rapidity as to obviate the necessity for alternative oxidizing agents, it is conceivable for meltwaters of delayed flow composition to deplete the store of dissolved atmospheric gases within solution, thereby relying on the microbial reduction of alternative materials for the continued acquisition of solutes. If this is the case, a switch in the mechanism of solute acquisition from a predominantly microbial mechanism operating under sub-oxic, reducing conditions to an inorganic regime utilising dissolved atmospheric gases would be expected to accompany the evolution of the hydrological system from a delayed to quick flow configuration. However, such a switch has yet to be documented in the literature. This paper therefore uses major ion chemistry and environmental isotopic analysis of $\delta^{15} \mathrm{~N}-\mathrm{NO} 3, \delta^{18} \mathrm{O}-\mathrm{SO} 4$ and $\delta^{13} \mathrm{C}$-DIC to identify this chemical switch during evolution of the subglacial drainage system at a High Arctic polythermal glacier, Midre Lovénbreen. 


\section{Methodology}

\section{Field site}

Midre Lovénbreen is a high Arctic polythermal glacier situated on the Brøggerhalvøya peninsula in North West Spitsbergen $\left(78.53^{\circ} \mathrm{N}\right.$ and $\left.12.04^{\circ} \mathrm{E}\right)$. It comprises cold ice at the surface, snout and margins, and a temperate basal layer in the central upper part of the glacier (Björnsson et al., 1996). Meltwater accesses the bed of the glacier via moulins in the accumulation area, later emerging as a pressurised subglacial upwelling at the terminus (Hodson and Ferguson, 1999). The location of the drainage upwelling varies each season, potentially governed by rapid frontal retreat of the glacier reconfiguring the internal drainage system on an annual basis (Rippin et al., 2003). Samples of subglacial water were obtained during both summer 2002 and 2003. During 2002, these were collected directly from the pressurised subglacial upwelling prior to any mixing with supraglacial melt water. However, during summer 2003, the upwelling emerged in two spatially separate locations. Initially emerging as a small anoxic spring on the eastern side of the catchment, this upwelling eventually ceased to flow and was duly replaced by a much larger outburst on the glacier surface in a location logistically difficult to access. Subglacial meltwater samples collected during summer 2003 are therefore presented as two discrete data sets rather than a continuous time series; the first representing meltwater of delayed flow and the latter sampled a few meters downstream of the larger upwelling emerging later in the season and representing meltwater of quick flow origin (Figure 1). The geology beneath the glacier consists of basement rocks belonging to the Lower, Middle and Upper Proterozoic and are predominantly composed of phyllites and beds of quartzite. More strongly metamorphosed rocks to the south of the phyllites include mica schists and beds of marble beneath the 
accumulation area of the glacier (Hjelle, 1993). Organic carbon contents of the bedrock typically average $0.07 \%(n=8$, range $=0.03$ to $0.3 \%)$ whilst total sulphur represents a much more dominant component averaging 1650ppm $(n=6$, range $=50$ to 5020ppm) (Wynn, 2004).

\section{Field Sampling}

Pre-melt supraglacial snowpack samples were collected in April 2002 and June 2003 following methods of Sickman et al. (2001) and Hodson et al. (2004), in order to establish the chemical composition of the snowpack serving as an input to the subglacial drainage system. Meltwater samples emerging from the subglacial outlets during summer 2002 and 2003 were collected for major ion analysis and filtered immediately in the field using a handheld Nalgene vacuum unit and $0.45 \mu \mathrm{m}$ cellulose nitrate filters to prevent further reaction with suspended sediment. All samples were stored airtight in pre-rinsed $60 \mathrm{ml}$ polyethylene Nalgene bottles and refrigerated awaiting further analysis.

Dissolved Oxygen (D.O.) concentrations were determined in the field using the Winkler titration method based on test kit reagents supplied by Merck. Sample $\mathrm{pH}$ was determined using a Hannah HI 1297D pH/ORP/temperature electrode following the method adapted from McQuaker et al. (1983).

Discharge and electrical conductivity were monitored continuously during summer 2002 at a proglacial river monitoring site located approximately $1 \mathrm{~km}$ downstream of the subglacial upwelling (Figure 1). Conductivity was logged using a Campbell 247 combined conductivity/temperature probe, and water stage measured using a 
Campbell scientific PDCR 1830 pressure transducer. A stage-discharge relationship was calculated using cross channel profiles of water depth and velocity using the midpoint method (Shaw, 1994).

Samples for isotopic analysis were collected in polyethylene jerry cans and bags for subglacial meltwater and pre-melt snow samples respectively (pre-rinsed using sample melt water), and transported back to the laboratory for processing. Snow samples for isotopic analysis were collected from the same location as the samples taken for chemical composition (Figure 1) and followed the field sampling methodology of Heaton et al., (2004). The snow was melted by immersing the plastic bags in warm water, and the liquid sample mixed in 1201 polyethylene drums (Heaton et al., 2004). Nitrate concentrations of all isotopic samples were determined as nitrite by spectrophotometry following cadmium reduction in the field laboratory to determine the quantity of water required to obtain $1 \mathrm{mg} \mathrm{NO}_{3}-\mathrm{N}$. To prevent further chemical reaction and change in melt water sample composition, each sample was pressure filtered through a high capacity $0.45 \mu \mathrm{m}$ filter capsule. Filtration was undertaken within twelve hours of collection and samples were then transferred into collapsible jerry cans.

Melt water samples of 1 litre in volume were collected in the field for $\delta^{13} \mathrm{C}$-DIC determination and transported immediately back to the laboratory. Samples were pressure filtered through $0.45 \mu \mathrm{m}$ filters and added to $15 \mathrm{ml}$ of alkaline barium chloride solution. Barium carbonate precipitates were refrigerated, separated by filtration, oven dried at approximately $50^{\circ} \mathrm{C}$ and stored airtight in glass vials awaiting further analysis. 


\section{Major ion analysis}

Anions of chloride, sulphate, and nitrate were determined upon return to the UK using a Dionex DX 100 ion chromatograph. Based on repeat analysis of reference standard materials, precision was quoted as $0.72,3.35$, and $1.19 \%$ RSD (relative standard deviation) for nitrate, chloride and sulphate respectively. Total alkalinity (predominantly present as bicarbonate) was determined by titration with $1 \mathrm{mmol}$ acid (HCl) to an end point $\mathrm{pH}$ of 4.5 using BDH mixed indicator (Golterman et al., 1978). Precision calculated from repeat analysis of samples was quoted as 5\% RSD. Calcium and magnesium were analysed by Atomic Absorption Spectroscopy. Precision estimates from repeat analysis of reference standard materials of comparable concentrations to the samples under analysis were calculated as 0.27 and $2.46 \%$ RSD for calcium and magnesium respectively. Soluble ammonium was analysed using a FOSS-Tecator FIAstar 5000 flow injection analyser (FOSS-Tecator, 2000). Precision was calculated as $1.75 \%$ RSD from reference standards of comparable concentration to the samples being analysed.

\section{Sample concentration for isotope analysis}

Meltwaters collected for isotopic analysis were gravity-fed through cation and anion exchange resins; AG2-X8 and AG50W-X8 respectively (BIO-RAD, 2000a; BIORAD, 2000b) following the methodology of Chang et al. (1999). To contend with the high salt and low nitrate content typical of the subglacial meltwaters being sampled, cation and anion resin volumes of up to $20 \mathrm{ml}$ were used and deliberately loaded to less than full exchange capacity to prevent fractionation of nitrate isotopes (Silva et al., 2000; Heaton et al., 2004). 
Nitrate and sulphate were eluted from the anion exchange resins using $1 \mathrm{M}$ hydrobromic acid (Hwang et al., 1999). To alleviate potential contamination of isotopic measurements of inorganic nitrate with organic nitrogen and oxygen, acidic hydrobromic eluents obtained from the anion resins were gravity-fed through columns containing $\mathrm{Env}^{+}$resin (Jones Chromatography, 2001) enabling the removal of dissolved organic matter (DOM) (Heaton et al., 2004). During summer 2003, this step was undertaken in the field using a combination of amberlite XAD7-HP (Rohm and Haas, 2001) and Env ${ }^{+}$resin (Jones Chromatography, 2001) placed upstream and in series with the anion and cation exchange resins, thereby acting as precursor resins for the removal of DOM. Precipitation of sulphate from the acidic anion exchange resin eluant as barium sulphate was undertaken using a $1 \mathrm{M}$ barium chloride solution. Samples were refrigerated for 48 hours encouraging the growth and maturation of the barium sulphate crystals and subsequently centrifuged to aid separation from the remaining nitrate solution. The remaining eluant was processed to pure silver nitrate $\left(\mathrm{AgNO}_{3}\right)$ following methods of Chang et al. (1999) and Silva et al. (2000). Product silver nitrate was re-dissolved in $100 \mu 1$ of de-ionised water and frozen for storage.

\section{Mass spectrometric analysis}

${ }^{15} \mathrm{~N} /{ }^{14} \mathrm{~N}$ and ${ }^{18} \mathrm{O} /{ }^{16} \mathrm{O}$ ratios of product barium sulphate and silver nitrate were determined by combustion in an elemental analyser linked to a Thermo Finnigan Delta + XL continuous flow mass spectrometer. Reductive pyrolysis of samples within silver capsules yielded $\mathrm{CO}$ for determination of ${ }^{18} \mathrm{O} /{ }^{16} \mathrm{O}$ ratios versus VSMOW (international standard $=$ NBS-127), and oxidative combustion of samples within tin capsules yielded $\mathrm{N}_{2}$ for analysis of ${ }^{15} \mathrm{~N} /{ }^{14} \mathrm{~N}$ ratios (international standard = IAEA-N1). 
Within-run standard replication (1S.D) was $<0.5 \%$ and $<0.4 \%$ o for $\delta^{15} \mathrm{~N}$-NO3 and $\delta^{18} \mathrm{O}$ SO4 respectively. $\delta^{18} \mathrm{O}$ values of nitrate are not presented in this paper as only partial removal of dissolved organic matter from the product silver nitrate rendered the majority of samples too contaminated to detect a switch in subglacial isotopic signature commensurate with the change in hydrological regime. $\delta^{18} \mathrm{O}$ analysis of $\mathrm{H}_{2} \mathrm{O}$ was undertaken using the $\mathrm{CO}_{2}$ equilibration procedure. Values were calculated versus VSMOW using within-run laboratory standards. Replicate analysis of withinrun standards indicated a precision of $0.05 \%$ (1 S.D). $\delta^{13} \mathrm{C}$ of DIC (Dissolved Inorganic Carbon) present in crushed rock samples and as barium carbonate was liberated as $\mathrm{CO}_{2}$ and ${ }^{13} \mathrm{C} /{ }^{12} \mathrm{C}$ ratios determined on a VG Optima mass spectrometer versus VPDB (international standard $=$ NBS-19). Replicate analysis of within-run standards indicated a precision of $0.03 \%$ (1S.D).

Method testing of resin ion exchange and column elution procedures has been undertaken by Heaton et al. (2004). Recovery of an artificial solution mimicking the chemistry of snow at Ny-Ấlesund was found to be quantitative in terms of both yield and isotopic value for each chemical species studied (Heaton et al., 2004). Field sample replication ( 1 S.D) for $\delta^{15} \mathrm{~N}-\mathrm{NO} 3$ and $\delta^{18} \mathrm{O}-\mathrm{SO} 4$ was $1.83 \%$ and $0.19 \%$ respectively.

\section{Results}

Discharge and suspended sediment concentrations (turbidity) recorded downstream of the subglacial upwelling during summer 2002 are plotted and displayed in Figure 2. The rapid increase in discharge shortly after the emergence of the pressurised 
subglacial upwelling reflects the release of water from storage that accompanies the rapid establishment of a quick flow component at the glacier bed. This clearly observable change in the river hydrology is coincident with striking changes in its hydrochemistry that are outlined below.

Concentrations of D.O. and electrical conductivity (EC) emanating from the pressurised subglacial upwelling are presented in Table 1 and Figure 3. Meltwater at the onset of subglacial drainage is depleted in dissolved atmospheric oxygen and appears sub-oxic in nature, whereas later meltwater fractions appear fully oxygenated. As an indication of total solute concentration, the electrical conductivity of the subglacial meltwater decreases rapidly in accordance with the switch from low to high D.O.

Concentrations of nitrogen species emanating from the subglacial environment are given in Table 1. Nitrate concentrations are low prior to the change in D.O and EC described above, whereas ammonium concentrations show the opposite trend, being least concentrated when the meltwater output from the system is fully oxygenated. $\delta^{15} \mathrm{~N}$-NO3 signatures presented in Table 2 show a similar change as the ${ }^{15} \mathrm{~N} /{ }^{14} \mathrm{~N}$ ratios in initial fractions of subglacial runoff appear enriched in ${ }^{15} \mathrm{~N}$ in comparison to the later fractions of subglacial meltwater. These trends are illustrated in Figures $4 \mathrm{a}$ and 4b for summer 2002 and 2003 respectively.

Concentrations of sulphate and bicarbonate emanating from the subglacial upwellings at Midre Lovénbreen are summarised in Table 1. At the onset of the subglacial drainage, when D.O. concentrations were low, sulphate and bicarbonate 
concentrations were greatest, exceeding $1000 \mu \mathrm{eq} / \mathrm{l}$. Log partial pressures of $\mathrm{CO}_{2}$ are greatest during the initial subglacial flow configuration and decrease thereafter (Table $1)$.

Measured $\delta^{18} \mathrm{O}$-sO4 values summarised in Table 2 also appear to have switched in accordance with the marked changes in sulphate concentrations and the degree of oxygenation evident in the subglacial outflow waters (Figures $5 \mathrm{a}$ and $5 \mathrm{~b}$ ). $\delta^{13} \mathrm{C}$-DIC values further enable the mechanisms of solute acquisition within the anoxic phase of the subglacial drainage to be established.

\section{Discussion}

From these above descriptions, it appears that concomitant changes in the chemical and isotopic composition of subglacial runoff occur, which are associated with the development of the subglacial drainage system. Below, we contend that this reflects the development of a quick flow, oxygenated configuration at the expense of a delayed flow drainage system that is anoxic and closed to the atmosphere. This hypothesis forms the basis of the following discussion wherein the role of microbiological activity in influencing the chemical composition of subglacial meltwaters under sub-oxic conditions is given particular attention.

\section{Subglacial denitrification and reduction to ammonium}

Interpreted collectively, conditions of high EC, low D.O. and low nitrate concentrations (Table 1) indicate an environment of active chemical weathering, potentially operating under reducing conditions closed to the atmosphere. As nitrate 
is readily used as an oxidising agent in the absence of D.O., this may imply nitrate is being lost from the system through denitrification (Equations 1 and 2).

$14 \mathrm{NO}_{3}{ }^{-}+5 \mathrm{FeS}_{2}+4 \mathrm{H}^{+} \rightarrow 7 \mathrm{~N}_{2}+10 \mathrm{SO}_{4}{ }^{2-}+5 \mathrm{Fe}^{2+}+2 \mathrm{H}_{2} \mathrm{O}$

$4 \mathrm{NO}_{3}+5 \mathrm{C}+2 \mathrm{H}_{2} \mathrm{O} \rightarrow 2 \mathrm{~N}_{2}+4 \mathrm{HCO}_{3}+\mathrm{CO}_{2}$

The periodic disappearance of nitrate in subglacial meltwater has also been noted at Haut Glacier D’Arolla, Switzerland by Tranter et al. (1994) and at Midre Lovénbreen by Hodson et al. (2004). However, concentrations of ammonium show a negative covariance with nitrate. If denitrification is indeed the cause of low nitrate concentrations in the initial fractions of subglacial runoff, it is likely this could be proceeding by dissimilatory reduction of nitrate to ammonium (e.g. Samuelsson, 1985; Binnerup et al., 1992; Korom, 1992) (Equation 3), or may represent the release of ammonium from bedrock under anoxic conditions (e.g. Holloway et al., 1998; Mingram and Brauer, 2001).

$2 \mathrm{H}^{+}+\mathrm{NO}_{3}^{-}+2 \mathrm{CH}_{2} \mathrm{O} \rightarrow \mathrm{NH}_{4}^{+}+2 \mathrm{CO}_{2}+\mathrm{H}_{2} \mathrm{O}$

Based upon the kinetic isotope fractionation associated with denitrification, isotope enrichment factors for the bacterially mediated production of $\mathrm{N}_{2}\left(\varepsilon_{\mathrm{N} 2}-\mathrm{NO} 3 \approx \delta^{15} \mathrm{~N}_{2}-\right.$ $\delta^{15} \mathrm{~N}_{\mathrm{NO} 3}$ ) give values of -40 to $-5 \%$ (Kendall, 1998), encouraging a concentration of ${ }^{15} \mathrm{~N}$ in the remaining pool of reactant nitrate. ${ }^{15} \mathrm{~N} /{ }^{14} \mathrm{~N}$ ratios in initial fractions of subglacial runoff appear enriched in ${ }^{15} \mathrm{~N}$ when compared to the isotopic values of supraglacial source water (compare Tables 2 and 3 ) and later oxic fractions of 
subglacial runoff (Figures $4 \mathrm{a}$ and $4 \mathrm{~b}$ ). This likely reflects kinetic isotope fractionation associated with microbial denitrification under sub-oxic conditions (e.g. Böttcher et al., 1990; Wassenaar, 1995; Clark and Fritz, 1997; Panno et al., 2001; Schurmann et al., 2003; Lehmann, et al., 2003.; Einsiedl et al., 2004). Rapid displacement of this sub-oxic water during summer 2002 limits the displayed time series of delayed flow meltwater to just one sample (Figure 4a), although during summer 2003 early season discharge of delayed flow meltwater was much lower, thereby enabling a time series to be established. Isotope ratios of ${ }^{15} \mathrm{~N} /{ }^{14} \mathrm{~N}$ during summer 2003 demonstrate an increase in the quantity of each species produced under sub-oxic conditions with time until all the delayed flow meltwater had been purged from beneath the glacier (Figure 4b). It is possible this represents a gradual purging of water from more strongly anoxic pockets of sediment at the glacier bed which are increasingly distal to the early season subglacial drainage structure.

From Tables 2 and 3, it should also be noted that in both 2002 and 2003 the concentrations and $\delta^{15} \mathrm{~N}$ values of nitrate in the oxic quickflow waters (averaging $\approx 4$ $\mu$ eq/1 and $-4 \%$, respectively) are higher than those of the pre-melt snowpack (2-3 $\mu$ eq $/ 1$ and $-10 \%$ respectively). This implies the addition of nitrate by some process operating during or after melting of the snowpack. Possible processes include microbial oxidation of snowpack ammonium; or addition of nitrate from a subglacial source, for example rock-derived nitrogen (Wynn et al., submitted).

\section{Redox evolution and sulphide oxidation}


Traditional models of inorganic geochemistry ascribe the majority of subglacial solute acquisition to processes of sulphide oxidation and carbonate dissolution, often expressed through Equation 4;

$4 \mathrm{FeS}_{2(\mathrm{~s})}+16 \mathrm{CaCO}_{3(\mathrm{~s})}+15 \mathrm{O}_{2(\mathrm{aq})}+14 \mathrm{H}_{2} \mathrm{O}_{(\mathrm{l})} \rightleftarrows 16 \mathrm{Ca}^{2+}{ }_{(\mathrm{aq})}+16 \mathrm{HCO}_{3(\mathrm{aq})}^{-}+8 \mathrm{SO}_{4}{ }_{(\mathrm{aq})}^{2-}+4 \mathrm{Fe}(\mathrm{OH})_{3(\mathrm{~s})}$

As depicted by Table 1 and noted by several authors (Lamb et al., 1995; Tranter et al., 2002), sulphate concentrations in the subglacial environment of many glaciers may readily approach $1000 \mu \mathrm{eq} / \mathrm{l}$. Such concentrations can only be achieved through Equation 4 assuming the input supraglacial meltwaters are $>200 \%$ saturated with D.O., or through the presence of an additional oxidizing agent (Tranter et al., 2002; Bottrell and Tranter, 2002). The use of Fe III as an oxidizing agent in the microbially mediated production of high concentrations of sulphate has been hypothesised by Tranter et al. (2002) and tested by Bottrell and Tranter (2002) based on the oxygen isotopic composition of sulphate generated through either biological or abiological oxidation (Taylor et al., 1984; Van Everdingen and Krouse, 1985).

Based upon traditional models of sulphate acquisition, sulphide oxidation according to Equation 5 utilises just 1 of 4 oxygen atoms from water, the remaining oxygen incorporated into the sulphate molecule being sourced from $\mathrm{O}_{2}$.

$4 \mathrm{FeS}_{2(\mathrm{~s})}+15 \mathrm{O}_{2(\mathrm{aq})}+14 \mathrm{H}_{2} \mathrm{O}_{(\mathrm{l})} \rightleftarrows 16 \mathrm{H}_{(\mathrm{aq})}^{+}+4 \mathrm{Fe}(\mathrm{OH})_{3(\mathrm{~s})}+8 \mathrm{SO}_{4}{ }_{(\mathrm{aq})}^{2-}$

However, under anoxic conditions at the bed of the glacier, the microbially mediated production of sulphate from iron sulphide can be expressed through Equation 6, 
whereby the stoichiometry is such that all of the oxygen incorporated into the sulphate molecule is obtained from the surrounding water.

$\mathrm{FeS}_{2}+14 \mathrm{Fe}^{3+}+8 \mathrm{H}_{2} \mathrm{O} \rightarrow 2 \mathrm{SO}_{4}{ }^{2-}+15 \mathrm{Fe}^{2+}+16 \mathrm{H}^{+}$

These two oxygen sources have different $\delta^{18} \mathrm{O}$ values: $\delta^{18} \mathrm{O}$-atmO2 $\approx+23.7 \%$ (Horibe et al., 1973) and $\delta^{18} \mathrm{O}-\mathrm{H}_{2 \mathrm{O}} \approx-12.3 \%$ (average of measured values given in Table 2 ). The resultant sulphate molecules should therefore be isotopically distinct, providing a mechanism through which the relative significance of each reaction can be assessed. As the concern of this paper is based upon the changing oxygen isotopic signatures of sulphate obtained from bedrock weathering in the subglacial environment, isotopic signatures have been corrected for the influence of aerosol and marine sulphate sourced from the glacier snowpack, according to Equation 7 (after Bottrell and Tranter, 2002).

$\delta^{18} \mathrm{O}$-sO4 corr $=\delta^{18} \mathrm{O}$-sO4 bulk $-\left(\delta^{18} \mathrm{O}\right.$-sO4 snow $\left.\times f_{\text {SO4 snow }}\right) / f_{\text {SO4 weathering }}$

Whereby $\delta^{18} \mathrm{O}$-sO4 bulk and $\delta^{18} \mathrm{O}$-sO4 snow, depict the measured isotopic values of bulk subglacial and snowpack sulphate-oxygen. $f_{\mathrm{SO} 4 \text { snow }}$ and $f_{\mathrm{SO} 4 \text { crustal }}$ represent the molar fraction of sulphate obtained from snowmelt and bedrock weathering respectively, calculated after Sharp et al., (1995) (Equations 8 and 9);

$f_{\mathrm{SO} 4 \text { snow }}=\left(\mathrm{SO}_{4} / \mathrm{Cl}\right)_{\text {snow }} \times \mathrm{Cl}_{\text {subglacial }}$

$f_{\text {SO4 crustal }}=1-f_{\text {SO4 snow }}$ 
$\left(\mathrm{SO}_{4} / \mathrm{Cl}\right)_{\text {snow }}$ represents the ratio of sulphate to chloride in the unmelted spring snowpack and $\mathrm{Cl}_{\text {subglacial }}$ is the concentration of chloride present within the subglacial melt waters. Corrected values are presented in Tables 1 and 2 and Figures 5a and 5b.

Due to rapid isotopic equilibration between intermediate sulphur species of lower oxidation state $\left(\mathrm{SO}_{2}\right.$ and $\left.\mathrm{SO}_{3}{ }^{-}\right)$and water, much of the intermediate $\delta^{18} \mathrm{O}-\mathrm{sO} 2$ isotopic signature is effectively lost. Subsequent rates of isotopic exchange between sulphate and water however, are extremely slow (Lloyd, 1967) rendering up to three of the four oxygen atoms in all sulphate molecules to be sourced from $\mathrm{H}_{2} \mathrm{O}$, irrespective of the sulphide oxidation pathway. This problem of isotopic equilibration was overcome by assuming that only the fourth oxygen atom incorporated into the sulphate reflected its origin from $\mathrm{O}_{2}$ or $\mathrm{H}_{2} \mathrm{O}$. Sulphate containing less than $25 \%$ of atmospheric $\mathrm{O}_{2}$ was therefore assumed to have been at least partly produced under conditions of anoxia by Equation 5 (Bottrell and Tranter, 2002). Assuming an isotopic enrichment of $-8.7 \%$ during the incorporation of oxygen from atmospheric $\mathrm{O}_{2}$ into sulphate molecules (Lloyd, 1968), a threshold value of $\delta^{18} \mathrm{O}$ can be calculated according to the methodology of Bottrell and Tranter (2002) and Equation 10.

$\delta^{18} \mathrm{O}_{\text {threshold }}=[(23.7-8.7) \times 0.25]+\left(0.75 \times \delta^{18} \mathrm{O}_{\mathrm{H} 2 \mathrm{O}}\right)$

Subglacial $\delta^{18} \mathrm{O}_{\mathrm{H} 2 \mathrm{O}}$ signatures ranged between $-12.46 \%$ o to $-12.74 \%$ or summer 2002 and $-11.63 \%$ to $-12.74 \%$ or for summer 2003 , yielding $\delta^{18} \mathrm{O}_{\text {threshold }}$ values of $-5.6 \%$ o to $-5.8 \%$ and $-5.0 \%$ to $-5.5 \%$ for summer 2002 and 2003 respectively. Corrected $\delta^{18} \mathrm{O}-$ so4 values are displayed in Table 2 and plotted in Figures $5 \mathrm{a}$ and $5 \mathrm{~b}$ in comparison to 
the theoretically calculated threshold value. The sulphate $\delta^{18} \mathrm{O}$ value of the delayed flow meltwater lies below the calculated threshold, indicating sulphate to have been formed under at least partly anoxic conditions, probably by the reduction of iron III. Such sub-oxic conditions likely formed during the winter when the subglacial system

was closed to the atmosphere. Again, isotope ratios of ${ }^{34} \mathrm{~S} /{ }^{32} \mathrm{~S}$ during summer 2003 demonstrate an increase in the quantity of each species produced under sub-oxic conditions with time (Figure 5b) and probably represents a gradual purging of water from more strongly anoxic pockets of sediment at the glacier bed which are increasingly distal to the early season subglacial drainage structure.

A rapid increase in $\delta^{18} \mathrm{O}$-sO4 values compared to the calculated oxic/anoxic threshold occurs in accordance with the rapid switch between delayed to quick flow subglacial configuration and the increase in D.O. concentrations towards saturation. This suggests the subglacial drainage network to have switched to an open system, establishing a connection with the supraglacial environment. Fluxes of quick flow oxygenated meltwater from the glacier surface enable the displacement of sub-oxic delayed flow water and the re-establishment of oxic conditions at the glacier bed for the remainder of the melt season ( $c f$ Bottrell and Tranter, 2002).

\section{Sources of bicarbonate in the subglacial drainage system}

Under open system conditions, DIC present in glacial meltwater is partly a product of the aqueous dissolution of atmospheric $\mathrm{CO}_{2}$ (Equation 11);

$\mathrm{CO}_{2(\mathrm{aq})}+\mathrm{H}_{2} \mathrm{O}_{(\mathrm{l})} \leftrightarrow \mathrm{H}_{(\text {(aq) }}^{+}+\mathrm{HCO}_{3}^{-}{ }_{(\mathrm{aq})}^{-}$

carbonate hydrolysis (Equation 12); 
$2 \mathrm{CaCO}_{3(\mathrm{~s})}+\mathrm{H}_{2} \mathrm{O}_{(\mathrm{l})} \leftrightarrow 2 \mathrm{Ca}^{2+}+\mathrm{HCO}_{3}^{-{ }_{(\mathrm{aq})}}+\mathrm{CO}_{3}{ }^{2-}+\mathrm{OH}^{-}{ }_{(\mathrm{aq})}$

carbonation reactions involving both silicates and carbonates (Equations 13 and 14 respectively);

$\mathrm{CaAl}_{2} \mathrm{SiO}_{8(\mathrm{~s})}+2 \mathrm{CO}_{2(\mathrm{aq})}+2 \mathrm{H}_{2} \mathrm{O}_{(\mathrm{l})} \leftrightarrow \mathrm{Ca}^{2+}{ }_{(\mathrm{aq})}+2 \mathrm{HCO}_{3}^{-}{ }_{(\mathrm{aq})}^{-}+\mathrm{H}_{2} \mathrm{Al}_{2} \mathrm{SiO}_{8(\mathrm{~s})}$

$\mathrm{CaCO}_{3(\mathrm{~s})}+\mathrm{CO}_{2(\mathrm{aq})}+\mathrm{H}_{2} \mathrm{O}_{(\mathrm{l})} \leftrightarrow \mathrm{Ca}^{2+}{ }_{(\mathrm{aq})}+2 \mathrm{HCO}_{3}^{-}{ }_{(\mathrm{aq})}^{-}$

and/or acid dissolution of carbonate and dolomitic bedrock (Equations 15 and 16 respectively);

$\mathrm{H}^{+}{ }_{(\mathrm{aq})}+\mathrm{CaCO}_{3(\mathrm{~s})} \leftrightarrow \mathrm{Ca}^{2+}{ }_{(\mathrm{aq})}+\mathrm{HCO}_{3}^{-}{ }_{(\mathrm{aq})}$

$2 \mathrm{H}^{+}{ }_{(\mathrm{aq})}+\mathrm{CaMg}\left(\mathrm{CO}_{3}\right)_{2(\mathrm{~s})} \leftrightarrow \mathrm{Ca}^{2+}{ }_{(\mathrm{aq})}+\mathrm{Mg}^{2+}+2 \mathrm{HCO}_{3}^{-}{ }_{(\mathrm{aq})}^{-}$

As the subglacial drainage is suggested to operate as a closed system during winter and early summer, concentrations of DIC should appear limited by the supply of $\mathrm{CO}_{2}$ and partial pressures of $\mathrm{CO}_{2}$ in the meltwater would be expected to be much lower than those measured in the atmosphere at $10^{-3.5}$ atmospheres. However, DIC concentrations under closed system conditions appear high, apparently unchecked by this limited supply of atmospheric $\mathrm{CO}_{2}$ (Table 1). Potential sources for this closed system DIC include; carbonate hydrolysis; acid dissolution, the $\mathrm{H}^{+}$being generated by sulphide oxidation through Equations 4 and 5; or microbial respiration of organic 
matter (Hodson et al., 2000; Tranter et al., 1997; Tranter et al., 2002a; Tranter et al., 2002b; Wadham et al., 2000), (e.g. Equations 17 and 18).

$4 \mathrm{Fe}(\mathrm{OH})_{3(\mathrm{~s})}+\mathrm{CH}_{2} \mathrm{O}+8 \mathrm{H}^{+} \rightleftarrows \mathrm{Fe}^{2+}+\mathrm{CO}_{2(\mathrm{~g})}+11 \mathrm{H}_{2} \mathrm{O}$

$\mathrm{SO}_{4}{ }^{2-}+2 \mathrm{CH}_{2} \mathrm{O} \rightarrow \mathrm{H}_{2} \mathrm{~S}+2 \mathrm{HCO}_{3}{ }^{-}$

To provenance the subglacial DIC concentrations between inorganic and organic sources, Equation 19 is used to calculate the amount of DIC released through inorganic hydrolysis and acid dissolution of the carbonate bedrock;

DIC ${ }_{\text {(hydrolysis and acid dissolution) }}=\mathrm{Ca}^{2+}$ crustal $+\mathrm{Mg}^{2+}$ crustal

Whereby $\mathrm{Ca}^{2+}$ crustal and $\mathrm{Mg}^{2+}$ crustal represent molar concentrations of crustal cations released during calcite and dolomite hydrolysis / dissolution, calculated after Sharp et al., (1995).

Whereas traditional provenance calculations assume all bicarbonate from acid dissolution to be sourced in a 2:1 molar ratio with sulphate released from sulphide oxidation (Equation 4), the oxidation of sulphide by iron III under closed system conditions holds the potential to generate greater quantities of bicarbonate from the dissolution of carbonate bedrock (Tranter et al., 2002). Consequently, use of the traditional bicarbonate provenance calculation under prevailing sub-oxic conditions is precluded. 
Table 4 compares measured DIC concentrations emanating from the closed phase of the subglacial drainage with theoretical concentrations of DIC produced via inorganic hydrolysis and acid dissolution and calculated according to Equation 19. The similarity between the calculated and measured values suggests the production of DIC through organic microbial respiration during the closed phase of the subglacial drainage has very little influence upon the magnitude of DIC released into the surrounding meltwaters. Further evidence towards the limited contribution of microbial respiration to the total DIC flux is seen through $\delta^{13} \mathrm{C}$-DIC values emanating from the closed phase of the subglacial drainage during 2003. Under closed system conditions, meltwater equilibrates first with the finite source of atmospheric $\mathrm{CO}_{2}$ entrained into the subglacial system and then dissolves an equivalent amount of DIC from the surrounding carbonate bedrock (Equation 13). In effect, half of the DIC is derived from dissolved atmospheric $\mathrm{CO}_{2}\left(\delta^{13} \mathrm{C}-\mathrm{CO} 2 \approx-8 \%\right.$ ) and half is sourced from the surrounding bedrock $\left(\delta^{13} \mathrm{C}\right.$-subglacial till $=-2 \%$; average $\left.\delta^{13} \mathrm{C}_{\text {-bedrock }} \approx-1 \%, n=8\right)$. Assuming there is no isotopic enrichment between the finite source of atmospheric $\mathrm{CO}_{2}$ and product DIC $\left(\varepsilon_{\mathrm{DIC}-\mathrm{CO} 2}=0 \%\right)$; no enrichment during the dissolution of carbonate bedrock to DIC $\left(\varepsilon_{\mathrm{DIC}-\mathrm{CaCO} 3}=0 \%\right)$; and assuming $\mathrm{CO}_{2}$ dissolution to be the only source of DIC, the $\delta^{13} \mathrm{C}$-DIC of the subglacial meltwaters should have an isotopic value of approximately -4.5 to $-5 \%$. Addition of DIC from organic microbial respiration $\left(\delta^{13} \mathrm{C}-\mathrm{CO}_{2} \approx-23 \%\right.$ ) should produce values of $\delta^{13} \mathrm{C}$-DIC isotopically lower than $-5 \%$ (after Wadham et al., 2004). However, values presented in Table 4 are all higher than the $-5 \%$ value. This suggests the majority of DIC in the closed phase of the subglacial system is obtained from an isotopically heavier source. This source is thought to be the surrounding carbonate bedrock whereby hydrolysis (Equation 12) and protons generated through sulphide oxidation (Equations 5 and 6) are capable of 
releasing DIC. Slightly higher $P\left(\mathrm{CO}_{2}\right)$ values associated with anoxic conditions (Table 1) may indicate a small release of $\mathrm{CO}_{2}$ into the meltwater from microbial respiration, although the isotopic signatures suggest this source may be overwhelmed by the release of DIC from the surrounding bedrock. Consequently, the rapid decrease in DIC concentration associated with the switch in hydrological regime appears to be mainly associated with a decrease in the proportion of rock-water contact time and proton generation through sulphide oxidation (Equations 5 and 6), rather than the change in redox status of the subglacial environment.

\section{Conclusions}

Major ion chemistry and environmental isotopic signatures have been obtained from a High Arctic subglacial upwelling allowing us to track the chemical evolution of the subglacial drainage system. Analyses of nitrogen, sulphur and carbon species present in the bulk subglacial meltwater have demonstrated the occurrence of a chemical switch as the drainage system matures. This chemical switch appears to be commensurate with the change in hydrological regime from a system dominated by delayed flow to one evacuating snow meltwaters of predominantly quick flow origin. Based upon traditional models of subglacial hydrochemistry, the acquisition of solutes was believed to be governed through inorganic weathering reactions, dependent upon the extent of rock-water contact and the availability of dissolved oxygen and carbon dioxide gases. However, data presented here concurs with the most recent literature, suggesting microbial catalysis and the utilisation of alternative oxidizing agents, must now be considered as a potentially important mechanism in governing the solute composition of subglacial discharge, in particular that of delayed flow origin. ${ }^{15} \mathrm{~N} /{ }^{14} \mathrm{~N}$ ratios of nitrate potentially demonstrate reducing conditions in early fractions of 
subglacial runoff and the utilisation of nitrate as an oxidising agent through denitrification. A chemical switch to conditions enabling evacuation of elevated nitrate concentrations appears to track the redox development of the subglacial drainage system when connection to the supraglacial environment and an increased discharge enables re-oxygenation of the system. ${ }^{18} \mathrm{O} /{ }^{16} \mathrm{O}$ isotopes of sulphate demonstrate an identical switch in redox status. Conversely, the majority of DIC emanating from beneath the glacier appears to be a direct result of varying degrees of rock-water interaction. $P\left(\mathrm{CO}_{2}\right)$ values elevated slightly above atmospheric concentrations may indicate a source of $\mathrm{CO}_{2}$ in addition to that entrained into the subglacial environment from the atmosphere. This is potentially sourced from microbial respiration of organic matter, although beneath this particular glacier, such an oxidation pathway appears to be of minimal significance to the solute output. In the absence of detailed microbiological data, isotopic and major ion analyses have thereby indicated the presence of microbial assemblages surviving beneath High Arctic glaciers, governing the solute composition of subglacial runoff and potentially influencing the mechanisms of solute release into neighbouring freshwater and marine ecosystems.

\section{Acknowledgements}

This work was supported by Natural Environment Research Council studentship funding to P. Wynn; CASE industrial partnership funding in association with the British Geological Survey; and Royal Society $20^{\text {th }}$ IGC funding to A. Hodson. 


\section{References}

Binnerup, S.J., Jensen, K., Revsbech, N.P., Jensen, M.H. and Sørensen, J. (1992) Denitrification, dissimilatory reduction of nitrate to ammonium, and nitrification in a bioturbated estuarine sediment as measured with ${ }^{15} \mathrm{~N}$ and microsensor techniques. Applied and Environmental Microbiology, 58 (1), 303-313

BIO-RAD (2000a) Instruction manual: AG 50W and AG MP-50 cation exchange resins. Bio-rad laboratories, LIT203 Rev B

BIO-RAD (2000b) Instruction manual: AG1, AG MP-1 and AG2 strong anion exchange resin. Bio-rad laboratories, LIT212 Rev C

Björnsson, H., Gjessing, Y., Hamran, S-E., Hagen, J.O., Liestøl, O., Pálsson, F. and Erlingsson, B. (1996) The thermal regime of sub-polar glaciers mapped by multifrequency radio-echo sounding. Journal of Glaciology, 42 (140), 23-32

Böttcher, J., Strebel, O., Voerkelius, S. and Schimdt, H-L. (1990) Using isotope fractionation of nitrate-nitrogen and nitrate-oxygen for evaluation of microbial denitrification in a sandy aquifer. Journal of Hydrology, 114, 413-424

Bottrell, S.H. and Tranter, M. (2002) Sulphide oxidation under partly anoxic conditions at the bed of Haut Glacier D’Arolla, Switzerland. Hydrological Processes, 16 (5), 959993 
Boulton, G.S and Hindmarsh, R.C.A (1987) Sediment deformation beneath glaciers: rheology and glaciological consequences. Journal of Geophysical Research, 92 (B9), 9059-9082

Chang, C.C.Y., Langston, J., Riggs, M., Campbell, D.H., Silva, S.R and Kendall, C. (1999) A method for nitrate collection for $\delta^{15} \mathrm{~N}$ and $\delta^{18} \mathrm{O}$ analysis from waters with low nitrate concentrations. Canadian Journal of Fisheries and Aquatic Science, 56, 1856 1864

Clark, I. D. and Fritz, P. (1997) Environmental isotopes in hydrogeology, Lewis

Collins, D.N. (1978) Hydrology of an Alpine glacier as indicated by the chemical composition of meltwater. Zeitschrift für Gletscherkunde und Glazialgeologie, 13, 219-238

Collins, D.N. (1979) Hydrochemistry of melt waters draining from an Alpine glacier. Arctic and Alpine Research, 11 (3), 307-324

Einsiedl, F., Maloszewski, P. and Stichler, W. (2004) Estimation of denitrification potential in a karst spring using the isotopes of ${ }^{15} \mathrm{~N}$ and ${ }^{18} \mathrm{O}$ of $\mathrm{NO}_{3}{ }^{-}$. Biogeochemistry (in press)

FOSS-Tecator (2000) Application note: Determination of ammonium in water by Fiastar $5000(\mathrm{AN} 5241)$ 
Golterman, H.L., Clymo, R.S. and Ohnstad, M.A.M. (1978) Methods for physical and chemical analysis of fresh waters, Second edition, IBP Handbook, number 8. Blackwell Scientific Publications, Oxford, Edinburgh, London, Melbourne

Heaton, T.H.E., Wynn, P.M. and Tye, A. (2004) Low ${ }^{15} \mathrm{~N} /{ }^{14} \mathrm{~N}$ ratios for nitrate in snow in the High Arctic $\left(79^{\circ} \mathrm{N}\right)$. Atmospheric Environment, 38, 5611-5621

Hjelle, A. (1993). Geology of Svalbard. Norsk Polarinstitutt, Oslo

Hodson A.J. and Fergusson, R.I. (1999) Fluvial suspended sediment transport from cold and warm based glaciers in Svalbard. Earth Surface Processes and Landforms, 24, $957-974$

Hodson, A., Tranter, M. and Vatne, G. (2000) Contemporary rates of chemical denudation and atmospheric $\mathrm{CO}_{2}$ sequestration in glacier basins: An Arctic perspective. Earth Surface Processes and Landforms, 25, 1447-1471

Hodson, A.J., Mumford, P.N., Kohler, J. and Wynn, P.M. (2004) The High Arctic glacial ecosystem: new insights from nutrient budgets. Biogeochemistry, In Press

Holloway, J. M., Dahlgren, R. A., Hansen, B. and Casey, W. H. (1998) Contribution of bedrock nitrogen to high nitrate concentrations in stream water. Nature, 395, 785-788

Hooke, R. Le. B., Laumann, T and Kohler, J (1990) Subglacial water pressures and the shape of subglacial conduits. Journal of Glaciology, 36 (122), 67-71 
Horibe, Y., Shigehara, K. and Takakuwa, Y. (1973) Isotope separation factor in carbon dioxide-water system and isotopic composition of atmospheric oxygen. Journal of Geophysical Research, 78, 2625-2629

Hwang, H.-H., Liu, C.-L.J., Hackley, K.C (1999) Method improvement for oxygen isotope analysis in nitrates. Geological Society of America Abstracts with programs, NorthCentral Section, 31, p. A-23 No. 5, April 22-23, Champaign, Il

Jones Chromatography (2001) Catalogue of sample preparation products and services, International sorbent technology

Kendall, C. (1998) Tracing nitrogen sources and cycling in catchments In: Kendall, C. and McDonnell, J.J. (eds.) Isotope tracers in catchment hydrology, Wiley

Korom, S.F. (1992) Natural denitrification in the saturated zone: A review. Water Resources Research, 28 (6), 1657-1668

Lamb, H.R., Tranter, M., Brown, G.H, Hubbard, B.P., Sharp, M.J., Smart, C.C., Willis, I.C. and Nielsen, M.K. (1995) The composition of subglacial meltwaters sampled from boreholes at the Haut Glacier D’Arolla, Switzerland. International Association of Hydrological Sciences Publication, 228, 395-403 
Lehmann, M.F., Reichert, P., Bernasconi, S.M., Barbieri, A and McKenzie, J.A (2003) Modelling nitrogen and oxygen isotope fractionation during denitrification in a lacustrine redox-transition zone. Geochimica Cosmochimica Acta, 67 (14) 2529-2542

Lliboutry, L. (1968) General theory of subglacial cavitation and sliding of temperate glaciers. Journal of Glaciology, 7, 21-58

Lloyd, R.M. (1967) Oxygen-18 composition of oceanic sulphate. Science, 156, 1228-1231

Lloyd, R.M (1968) Oxygen isotope behaviour in the sulphate-water system. Journal of Geophysical Research, 73, 6099-6209

McQuaker, N.R., Kluckner, P.D and Sandberg, D.K (1983) Chemical analysis of acidic precipitation: $\mathrm{pH}$ and acidity determinations. Environmental Science and Technology, $17,431-439$

Mingram, B. and Brauer, K. (2001) Ammonium concentration and nitrogen isotope composition in meta-sedimentary rocks from different tectonmetamorphic units of the European Variscan Belt. Geochimica et Cosmochimica Acta, 65 (2), 273-287

Nienow, P.W., Sharp, M.J and Willis, I.C (1998) Seasonal changes in the morphology of the subglacial drainage system, Haut Glacier D'Arolla, Switzerland. Earth Surface processes and Landforms, 23, 825-843 
Nye, J.F (1973) Water at the bed of a glacier Symposium on the hydrology of glaciers, IASH publication, Cambridge, 95, 189-194

Panno, S.V., Hackley, K.C., Hwang, H.H. and Kelly, W.R. (2001) Determination of the sources of nitrate contamination in karst springs using isotopic and chemical indicators. Chemical Geology, 179, 113-128

Parkes, J., Kivimaki, A.L., Bottrell, S.H, Raiswell, R., Skidmore, M Tranter, M. and Wadham, J.L. Microbial utilisation of bedrock components during chemical weathering in subglacial environments. Conference draft, Earth system processes Global meeting (June $24^{\text {th }}-28^{\text {th }}$, 2001)

Rippin, D., Willis, I., Arnold, N., Hodson, A.J., Moore, J., Kohler, J. and Björnsson, H. (2003) Changes in geometry and subglacial drainage of Midre Lovenbreen, Svalbard, determined from digital elevation models. Earth Surface Processes and Landforms, $28,273-298$

Rohm and Haas (2001) Product data sheet: Amberlite XAD7HP industrial grade polymeric adsorbent

Rothlisberger, H (1972) Water pressure in intra- and sub-glacial channels. Journal of glaciology, 11, 177-203 
Samuelsson, M-O. (1985) Dissimilatory nitrate reduction to nitrite, nitrous oxide and ammonium by Pseudomonas putrefaciens. Applied and Environmental Microbiology, $50(4), 812-815$

Schurmann, A., Schroth, M.H., Saurer, M., Bernasconi, S.M. and Zeyer, J. (2003) Nitrateconsuming processes in a petroleum-contaminated aquifer quantified using push-pull tests combined with $15 \mathrm{~N}$ isotope and acetylene-inhibition methods. Journal of contaminant hydrology, 1919, 1-19

Sharp, M., Tranter, M., Brown, G.H. and Skidmore, M. (1995) Rates of chemical denudation and $\mathrm{CO}_{2}$ drawdown in a glacier-covered Alpine catchment. Geology, 23, $61-64$

Sharp, M., Parkes, J., Cragg, B., Fairchild, I.J., Lamb, H. and Tranter, M. (1999) Widespread bacterial populations at glacier beds and their relationship to rock weathering and carbon cycling. Geology, 27 (2), 107-110

Shaw, E.M. (1994) Hydrology in practice, Chapman and Hall, London

Sickman, J.O., Laydecker, A. and Melack, J.M. (2001) Nitrogen mass balances and abiotic controls on $\mathrm{N}$ retention and yield in high-elevation catchments of the Sierra Nevada, California, United States. Water Resources Research, 37 (5), 1445-1461 
Silva, S. R., Kendall, C., Wilkison, D. H., Ziegler, A. C., Chang, C. C. Y. and Avanzino, R. J. (2000) A new method for collection of nitrate from freshwater and the analysis of nitrogen and oxygen isotope ratios. Journal of Hydrology, 228, 22-36

Skidmore, M., Foght, J.M. and Sharp, M. (2000) Microbial Life Beneath a High Arctic Glacier. Applied and Environmental Microbiology, 66 (8) 3214-3220

Taylor, B.E., Wheeler, M.C and Nordstrom, D.K (1984) Isotope composition of Sulphate in acid mine drainage as a measure of bacterial oxidation. Nature 308, 538-541

Tranter, M. and Raiswell, R. (1991) The composition of the englacial and subglacial component in bulk melt waters draining the Gornergletscher, Switzerland. Journal of Glaciology, 37 (125), 59-66

Tranter, M., Brown, G., Raiswell, R., Sharp, M. and Gurnell, A. (1993) A conceptual model of solute acquisition by Alpine glacial meltwaters. Journal of Glaciology, 39 (133), $573-581$

Tranter, M., Brown, G.H., Hodson, A., Gurnell, A.M. and Sharp, M.J. (1994) Variations in the nitrate concentration of glacial runoff in Alpine and sub-polar environments. IAHS Publication, 223, 299-311

Tranter, M., Sharp, M.J., Brown, G.H., Willis, I.C., Hubbard, B.P., Nielson, M.K., Wsmart, C.C., Gordon, S., Tulley, M. and Lamb, H.R. (1997) Variability in the chemical composition of in situ subglacial meltwaters. Hydrological Processes, 11, 59-77 
Tranter, M.., Sharp, M.J., Lamb, H.R., Brown, G.H., Hubbard, B.P. and Willis, I.C (2002a) Geochemical weathering at the bed of Haut Glacier d'Arolla, Switzerland - a new model. Hydrological processes, 16, 959-993

Tranter, M., Huybrechts, P., Munhoven, G., Sharp, M.J., Brown, G.H., Jones, I.W., Hodson, A,J., Hodgkins, R and Wadham, J.L (2002b) Direct effect of ice sheets on Terrestrial bicarbonate, sulphate and base cation fluxes during the last glacial cycle: minimal impact on atmospheric $\mathrm{CO}_{2}$ concentrations. Chemical Geology, 190, 33-44

Van Everdingen, R.O. and Krouse H.R. (1985) Isotope composition of sulphates generated by bacterial and abiological oxidation. Nature, 315, 395-396

Wadham, J.L., Tranter, M. and Dowdeswell, J.A. (2000) Hydrochemistry of melt waters draining a polythermal-based, high Arctic glacier, south Svalbard: II. Winter and early Spring. Hydrological processes, 14, 1767-1786

Wadham, J.L., Bottrell, S., Tranter, M. and Raiswell, R. (2004) Stable isotope evidence for microbial sulphate reduction at the bed of a polythermal high Arctic glacier. Earth and Planetary Science Letters, 219, 341-355

Wassenaar, L.I. (1995) Evaluation of the origin and fate of nitrate in the Abbotsford Aquifer using the isotopes of ${ }^{15} \mathrm{~N}$ and ${ }^{18} \mathrm{O}$ in $\mathrm{NO}_{3}{ }^{-}$Applied Geochemistry, 10, 391-405 
Weertman, J (1972) General theory of water flow at the base of a glacier or ice sheet. Reviews of Geophysics and Space Physics, 10, 287-333

Wynn, P (2004) The provenance and fate of nitrogen in arctioc glacial meltwaters: an isotopic approach. Unpublished Ph.D thesis. University of Sheffield

Wynn, P., Hodson A. J., Heaton, T.H.E and Chenery, S (Submitted) Microbial nitrate and the release of geologic-N within the subglacial environment of a high Arctic glacier. Earth and Planetary Science Letters 
Figures

Figure 1: Location map and sampling sites of Midre Lovénbreen, Svalbard

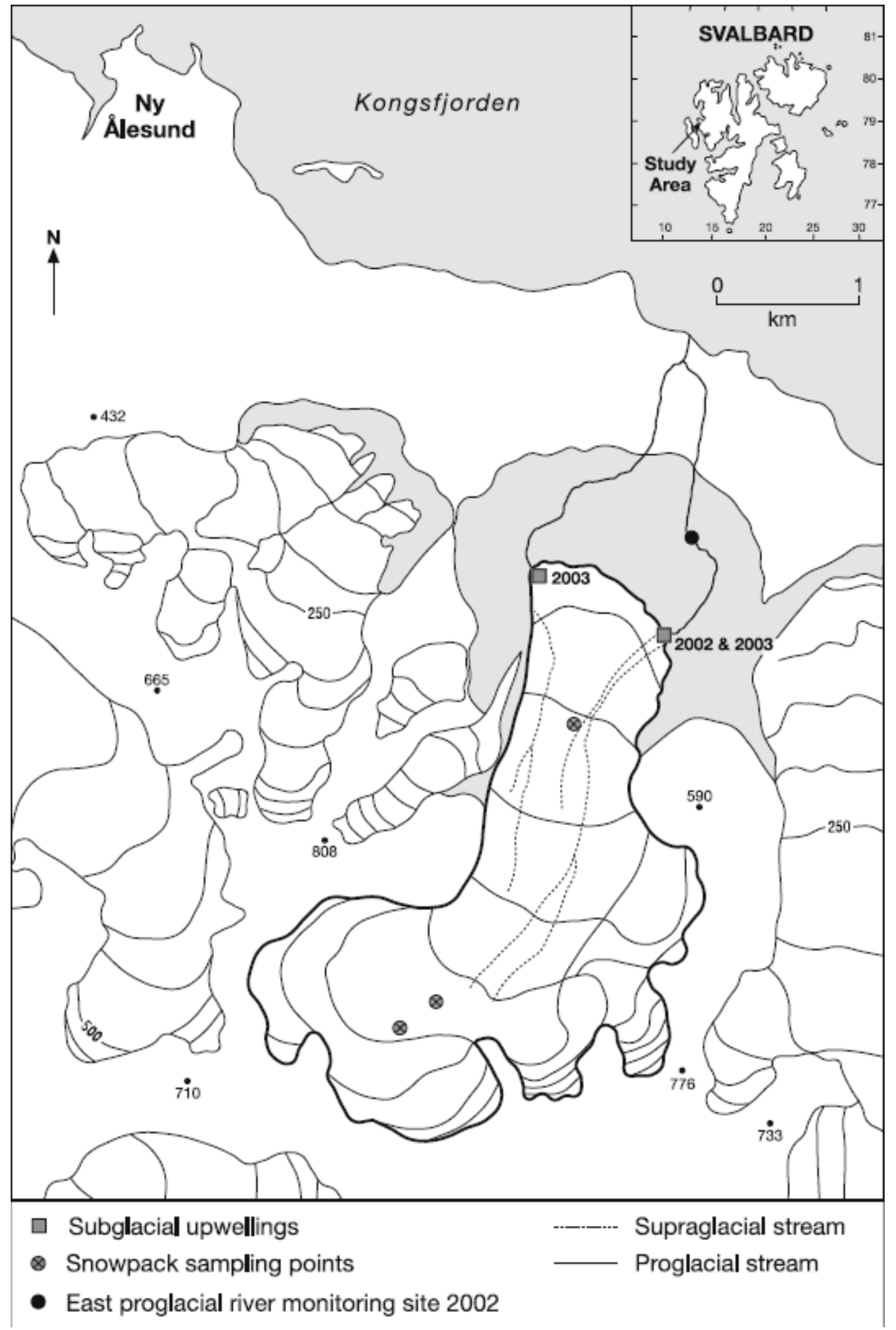


Figure 2: Discharge $\left(\mathrm{m}^{3} /\right.$ day) and turbidity (raw $\mathrm{mV}$ output to logger) time series of subglacial melt water discharging from the summer 2002 subglacial upwelling and east proglacial drainage

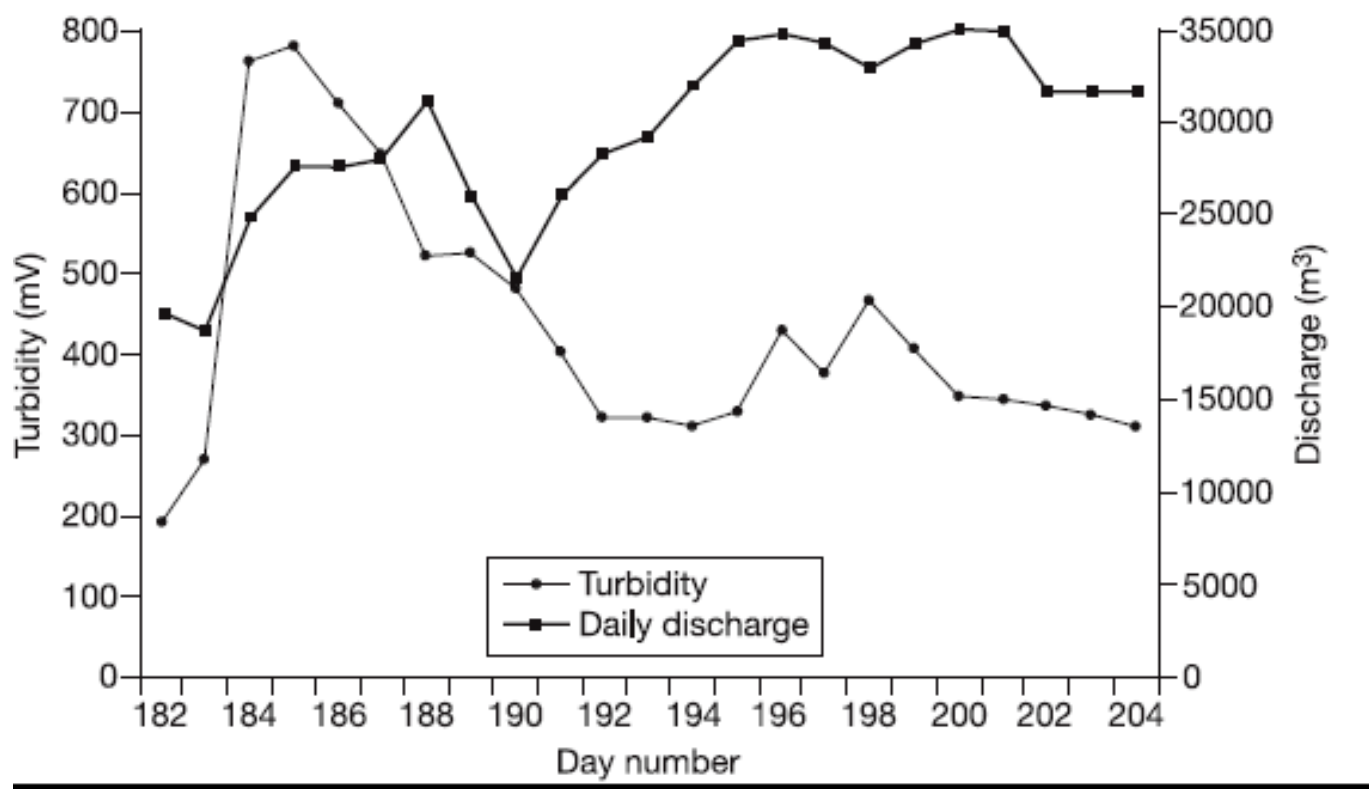


Figure 3: Dissolved oxygen (D.O.) (mg/l) and conductivity $(\mu \mathrm{S} / \mathrm{cm})$ time series of subglacial melt water emanating from the 2002 subglacial upwelling

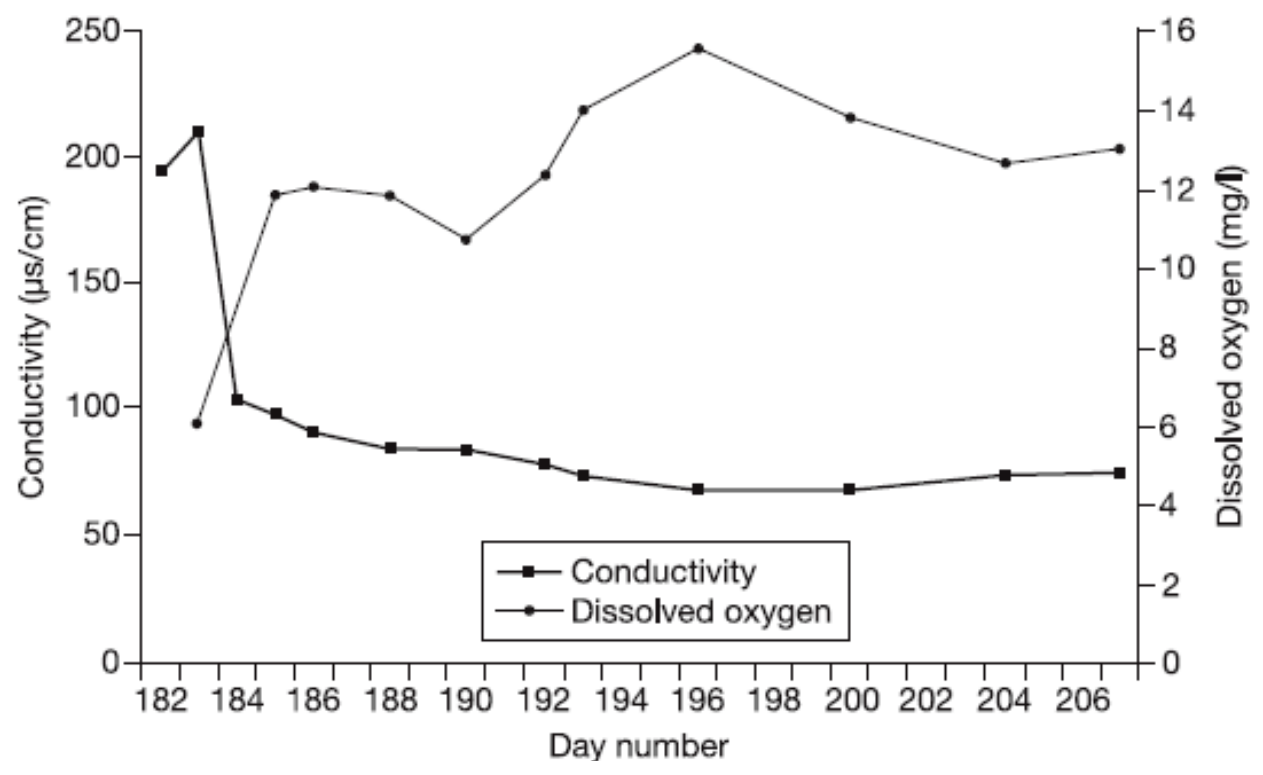


Figure 4a: $\delta^{15} \mathrm{~N}-\mathrm{NO}$ values of summer 2002 subglacial melt water

Figure 4b: $\delta^{15} \mathrm{~N}-\mathrm{NO} 3$ values of summer 2003 subglacial melt water
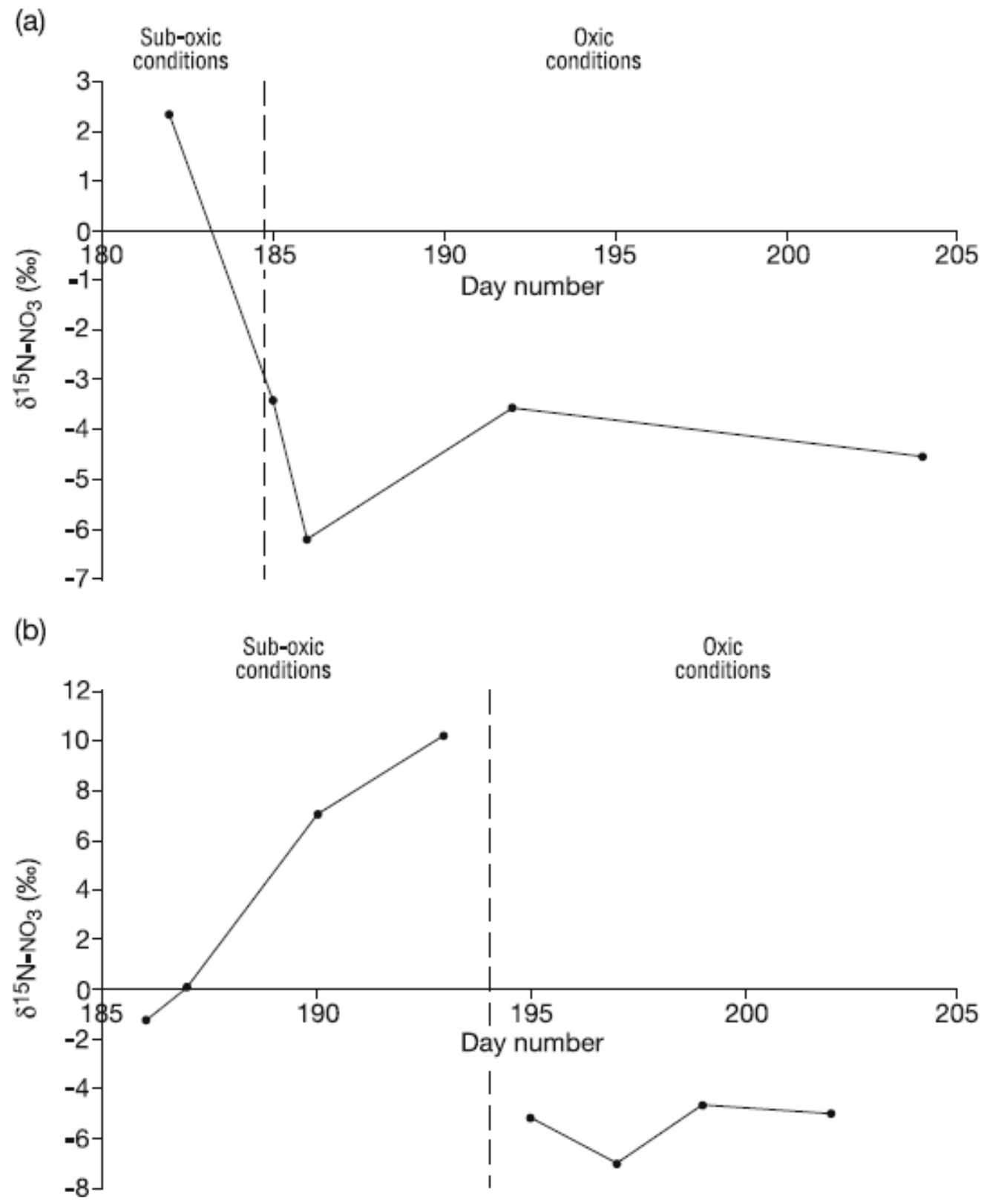
Figure 5a: $\delta^{18} \mathrm{O}$-sO4 emanating from the summer 2002 subglacial drainage in comparison to the calculated anoxic threshold (values are corrected for the influence of snowpack sulphate according to Equations 7-9)

Figure 5b: $\delta^{18} \mathrm{O}-\mathrm{sO} 4$ emanating from the summer 2003 subglacial drainage in comparison to the calculated anoxic threshold (values are corrected for the influence of snowpack sulphate according to Equations 7-9)
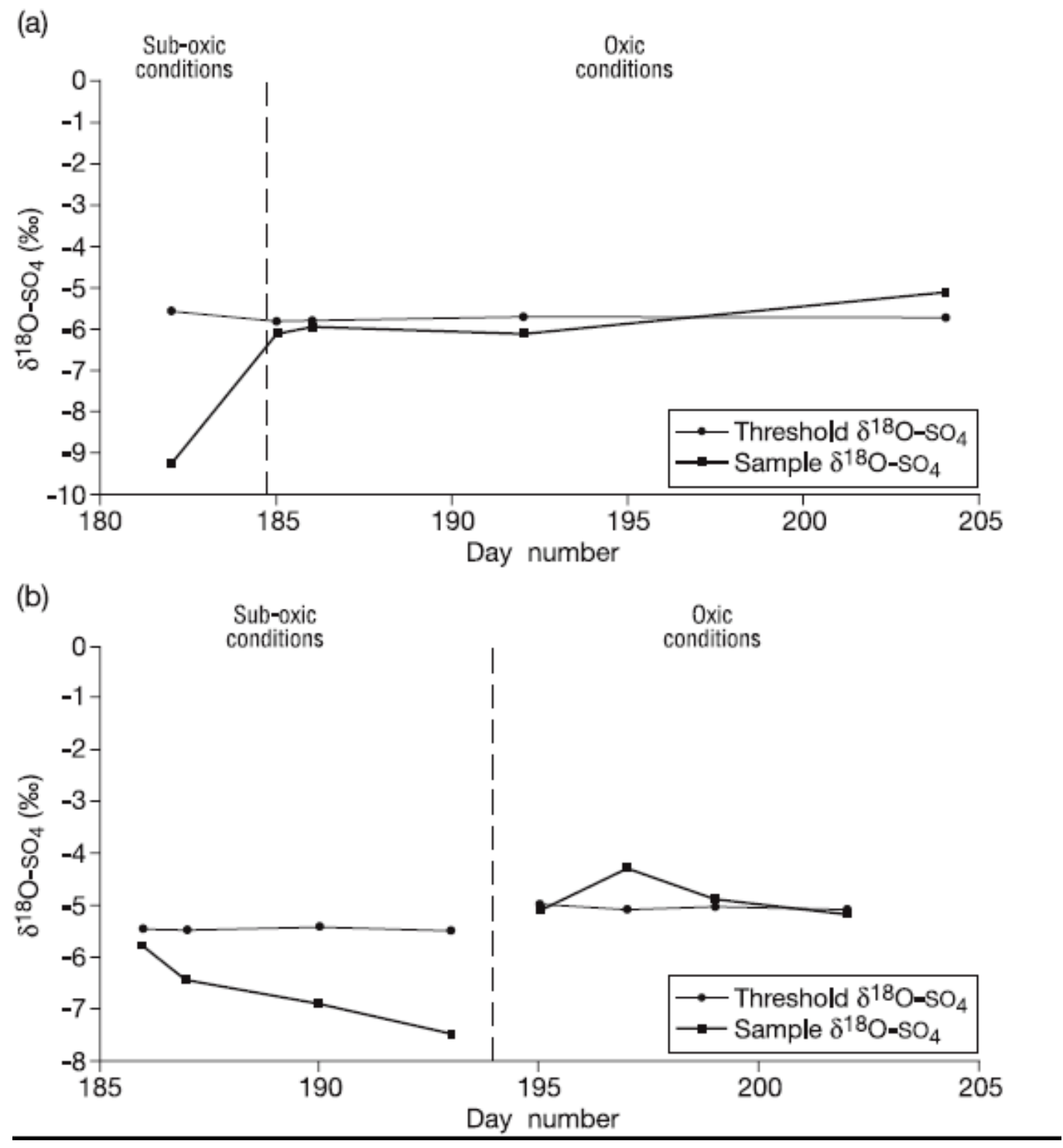


\section{Tables}

Table 1: Major ion chemical characteristics of subglacial delayed and quick flow meltwater components

\begin{tabular}{|c|c|c|c|c|c|c|c|c|}
\hline Subglacial melt water & Redox state & $\begin{array}{c}\text { Dissolved } \\
\text { Oxygen (mg/l) }\end{array}$ & $\mathrm{EC}\left(\mu \mathrm{s} \mathrm{\textrm {cm } ^ { - 1 } )}\right.$ & $\operatorname{NO3}(\mu \mathrm{M} / \mathrm{l})$ & $\mathbf{N H}_{4}^{+}(\mu \mathrm{M} / \mathrm{l})$ & $\mathrm{SO}_{4}(\mu \mathrm{M} / \mathrm{l})$ & $\mathrm{HCO}_{3}^{-}(\mu \mathrm{M} / \mathrm{l})$ & $P\left(\mathrm{CO}_{2}\right)$ \\
\hline Delayed flow 2002 & sub-oxic & $<6.0$ & $201(10.6)$ & $1.12(0.5)$ & $0.52(0.3)$ & $652.7(19.0)$ & $1224.4(84.6)$ & $-3.46(0.1)$ \\
\hline Quick flow 2002 & oxic & $12.4(1.5)$ & $79(15.4)$ & $4.27(0.6)$ & $0.14(0.1)$ & $150.5(28.4)$ & $580.5(93.1)$ & $-3.65(0.2)$ \\
\hline Delayed flow 2003 & sub-oxic & $2.4(0.4)$ & $157(8.6)$ & $2.96(1.0)$ & $0.17(0.1)$ & $367.7(35.0)$ & $1133.4(39.6)$ & $-3.46(0.1)$ \\
\hline Quick flow 2003 & oxic & 14.6 & $60(8.7)$ & $3.86(0.6)$ & $0.10(0.2)$ & $98.0(19.7)$ & $478.4(70.1)$ & $-3.65(0.2)$ \\
\hline
\end{tabular}

Values are means for $n=2$ to14 (whereby $n$ represents the number of field samples) with 1SD given in parentheses

Table 2: Isotopic characteristics of subglacial delayed and quick flow meltwater components

\begin{tabular}{|c|c|c|c|c|c|c|}
\hline Subglacial melt water & $n=$ & Redox state & $\delta^{15} \mathrm{~N}-{ }_{\mathrm{NO3}} *$ & $\delta^{18} \mathrm{O}-\mathrm{sO}_{4} *$ & $\delta^{13} \mathrm{C}$-DIC ${ }^{*}$ & $\delta^{18} \mathrm{O}_{-\mathrm{H} 2 \mathrm{O}} *$ \\
\hline Delayed flow 2002 & 1 & sub-oxic & +2.3 & -9.2 & ----- & -12.46 \\
\hline Quick flow 2002 & 4 & oxic & $-4.5(1.3)$ & $-5.7(0.5)$ & ----- & $-12.69(0.1)$ \\
\hline Delayed flow 2003 & 4 & sub-oxic & $+4.0(5.5)$ & $-6.6(0.7)$ & $-3.7(0.1)$ & $-12.27(0.1)$ \\
\hline Quick flow 2003 & 4 & oxic & $-4.1(1.1)$ & $-4.8(0.4)$ & ----- & $-11.70(0.2)$ \\
\hline
\end{tabular}

$* \delta \mathrm{X}_{\text {sample, }}$ in \%o $=\left[\left(\mathrm{R}_{\text {sample }} /\left(\mathrm{R}_{\text {standard }}\right)-1\right] \times 1000\right.$

where: for $\mathrm{X}={ }^{15} \mathrm{~N}, \mathrm{R}={ }^{15} \mathrm{~N} /{ }^{14} \mathrm{~N}$, standard $=$ atmospheric $\mathrm{N}_{2}$; for $\mathrm{X}={ }^{18} \mathrm{O}, \mathrm{R}={ }^{18} \mathrm{O} /{ }^{16} \mathrm{O}$, standard $=\mathrm{VSMOW}$; for $\mathrm{X}={ }^{13} \mathrm{C}, \mathrm{R}={ }^{13} \mathrm{C} /{ }^{12} \mathrm{C}$, standard $=$ VPDB

$n$ represents the number of field samples. 1SD is given in parentheses. 
Table 3: Major ion and isotopic characteristics of pre-melt snowpack

\begin{tabular}{|c|c|c|c|c|c|c|c|c|}
\hline Pre-melt snowpack & $n=$ & $\mathrm{Cl}(\mu \mathrm{M} / \mathrm{I})$ & NO3 $(\mu \mathrm{M} / \mathrm{l})$ & $\mathrm{NH}_{4}^{+}(\mu \mathrm{M} / \mathrm{l})$ & $\mathrm{SO}_{4}(\mu \mathrm{M} / \mathrm{l})$ & $\delta^{15} \mathrm{~N}-\mathrm{NO3}^{*}$ & $\delta^{18} \mathrm{O}-$ sO4 $^{*}$ & $\delta^{18} \mathrm{O}_{-\mathrm{H} 2 \mathrm{O}} *$ \\
\hline Snowpack 2002 & 2 & $102.9(5.5)$ & $1.6(0.1)$ & $1.3(0.1)$ & $12.4(0.3)$ & $-9.9(0.02)$ & $+9.3(0.3)$ & $-12.41(1.0)$ \\
\hline Snowpack 2003 & 1 & 114.8 & 3.1 & 5.1 & 10.4 & $\begin{array}{l}-9.8 \\
\end{array}$ & +8.6 & -11.94 \\
\hline
\end{tabular}

$* \delta \mathrm{X}_{\text {sample }}$, in \%o $=\left[\left(\mathrm{R}_{\text {sample }} /\left(\mathrm{R}_{\text {standard }}\right)-1\right] \times 1000\right.$

where: for $\mathrm{X}={ }^{15} \mathrm{~N}, \mathrm{R}={ }^{15} \mathrm{~N} /{ }^{14} \mathrm{~N}$, standard = atmospheric $\mathrm{N}_{2}$; for $\mathrm{X}={ }^{18} \mathrm{O}, \mathrm{R}={ }^{18} \mathrm{O} /{ }^{16} \mathrm{O}$, standard $=\mathrm{VSMOW}$

$n$ represents the number of field samples. 1SD given in parentheses.

Table 4: Concentrations of bicarbonate, calcium and magnesium in the delayed flow meltwaters of the subglacial drainage

\begin{tabular}{|c|c|c|c|c|c|}
\hline Subglacial meltwater & $n=$ & Ca $a_{\text {crustal }}(\mu M / \mathrm{l}) *$ & $M g_{\text {crustal }}(\mu M / l) *$ & $\mathrm{DIC}_{\text {acid dissolution }}(\mu \mathrm{M} / \mathrm{l})^{\dagger}$ & $\mathrm{DIC}_{\text {Total }}(\mu \mathrm{M} / \mathrm{l})^{\dagger \dagger}$ \\
\hline Delayed flow 2002 & 2 & $875.8(37.9)$ & $251.5(12.3)$ & $1127.3(50.1)$ & $1224.4(84.6)$ \\
\hline Delayed flow 2003 & 8 & $637.3(35.7)$ & $256.8(13.7)$ & $893.9(49.2)$ & $1133.4(39.6)$ \\
\hline
\end{tabular}

$* \mathrm{X}_{\text {crustal }}$ in $\mu \mathrm{M} / \mathrm{l}=1-(\mathrm{X} / \mathrm{Cl})_{\text {snow }} \times \mathrm{Cl}_{\text {subglacial }}$ (calculated after Sharp et al., 1995),

where: $(\mathrm{X} / \mathrm{Cl})_{\text {snow }}$ represents the ratio of ions to chloride in the unmelted spring snowpack and $\mathrm{Cl}_{\text {subglacial }}$ is the concentration of chloride present within the subglacial melt waters.

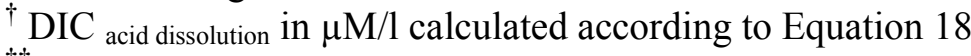

${ }^{\dagger} \mathrm{DIC}_{\text {total }}$ in $\mu \mathrm{M} / 1$ represents the total amount of DIC measured in the subglacial meltwaters.

$n$ represents the number of field samples. 1 SD given in parentheses. 